\title{
Muslim Stand-Up Comedy in the US and the UK: Incongruity, Everydayness, and Performativity
}

\author{
Lamiae Aidi
}

Citation: Aidi, Lamiae. 2021. Muslim Stand-Up Comedy in the US and the UK: Incongruity, Everydayness, and Performativity. Religions 12: 801. https://doi.org/ $10.3390 /$ rel12100801

Academic Editors: Chris Allen and Christina Verousi

Received: 17 August 2021

Accepted: 10 September 2021

Published: 26 September 2021

Publisher's Note: MDPI stays neutral with regard to jurisdictional claims in published maps and institutional affiliations.

Copyright: (c) 2021 by the author. Licensee MDPI, Basel, Switzerland. This article is an open access article distributed under the terms and conditions of the Creative Commons Attribution (CC BY) license (https:// creativecommons.org/licenses/by/ $4.0 /)$.
Humanities Department, Centre for Interdisciplinary Studies in Society and Culture (CISSC), Concordia University, Montreal, QC H3G 2V4, Canada; lamiaeaidi@gmail.com

\begin{abstract}
The objectives of this article are two-fold: to provide a review of the major figures and trends in Muslim American comedy and discuss certain techniques and approaches that have been used by stand-up comedians to counter predominant and discriminatory perceptions of the "Other". To reiterate film critic Jack Shaheen's argument in Reel Bad Arabs: How Hollywood Vilifies a People, the Western public is fed constructions of Islam as a "problem"; the terms "Arab" and "Muslim" are interchangeably used; Muslim men are depicted as "terrorists"; and Muslim women are depicted as "veiled and oppressed". Much has been written on the generation and effect of stereotypes promoted by popular culture. However, stereotyped groups also use popular culture to speak for themselves. Popular culture also functions to resist, counter, push back against, and subvert stereotypes. In other words, the "Other" can speak for him or herself through popular culture as a means of contesting stereotypes that define Muslims and Arabs in terms of cultural and religious understandings that narrowly categorize individuals through attributes such as religiosity and femininity. This potential is being realized by second-generation Muslims familiar with the platforms created and provided by other marginalized groups in Anglo-American popular culture, and their work has come into its own especially in the aftermath of $9 / 11$, a time that saw both the intensification of stereotypes and heightening of Muslim American consciousness. I concentrate on these specific stand-up comedians in the US and the UK, despite the fact that there are others in the diaspora who discuss Islamophobia, because these American and British comedians address all of the three most common stereotypes of Muslims: "Arab = Muslim", the "terrorist", and the "veiled and oppressed woman".
\end{abstract}

Keywords: Islamophobia; stereotypes; Muslim stand-up comedy; US; UK; Tissa Hami; Shazia Mirza

\section{Introduction}

Stand-up comedy is a performance in which individual comedians use a narrative consisting of fictional and semi-autobiographical jokes and stories to speak to audiences about various issues. Although the term "comedian" did not come into being until the 1890s, stand-up comedy began in America in the 1840s, when minstrel shows incorporated blackface monologues of Jim Crow, a theater character created by Thomas D. Rice. Rice was an actor who studied African American slave dance and music culture. His 1830s theater performance of Crow, a slave who sang while working the fields, includes him painting his face and hands black and singing a song that he also created, titled "Jump Jim Crow". Nonetheless, subsequent minstrel performances in the 1940s drawing on the Crow character did not include music and consisted only of monologue. In other words, although inspired by a singing character made for theater, stand-up comedy in the nineteenth century US began with the spoken word.

Meanwhile, in the UK, stand-up comedy was initially in the shape of a song, and early performers from the 1800 s were referred to as "lions comiques", "seriocomics", and "buffo vocalists". Comic songs of music hall by writers such as Max Beerbohm, Maurice Willson Disher, H. Chance Newton, and Dion Clayton Calthrop geared at a middle- and upper-class audience then began to add a single spoken section at the end of their songs. 
This trend continued up until the late 1970s when stand-up comedy eventually developed into spoken stand-up as we know it today.

Humor relevant to Afro-Caribbeans is a predominant theme in British humor, and during the Victorian Age, jokes drew on Darwinism to physically ridicule Black people. This trend continued through various immigration influxes, with comedians such as Charlie Williams saying,

“But it's these Pakistanis you know, they freeten me. By, i'n't there a lot, i'n't there, eh? They're comin' ovver 'ere, aren't they, on barrows, camels, oil slicks, owt they can get on, aren't they?" With regard to Africans, Jos White said, "You should emigrate. And the place to go to is Africa-it's empty!". (Double 1991)

This is to say that there are two main differences between the evolution of stand-up comedy in the UK and in the US. The first difference is that music hall stand-up in the UK began in the shape of a song, whereas in the US, it began with the shape that it is in now, that of the spoken word. The second difference is that, while both British and American stand-up comedy audiences now reflect members of all classes, British stand-up did not at first. With the exception of some Vaudeville audiences after WWII, the majority of comedy spectators in the UK were middle-class music hall attendees. While the US and UK contexts of the history of stand-up comedy are different, comedians in both countries today address the same common stereotypes of Muslims, first pointed out by Jack Shaheen (2001) in Reel Bad Arabs: How Hollywood Vilifies a People.

Thus, initially, in the nineteenth century, American stand-up was used to mock ethnic and racial groups, primarily African Americans; this is seen not only in stand-up monologues by Crow characters but also in the various minstrel shows, where most African American characters were performed by White actors. Racial stereotypes, inspired by social Darwinism, were also a staple of stand-up comedy in the early days of the British music halls. British comedians in this tradition made fun of the working class as well, which is why audiences were mostly of the middle and upper classes.

Then, performers from marginalized groups themselves joined the art of stand-up and reversed that tradition by contributing to topics through their own unique perspectives and to performance techniques in their own ways. This is the beginning of what is referred to as "ethnic" stand-up comedy, what comedian and author Joanne Gilbert, in "Performing Marginality: Comedy, Identity, and Cultural Critique", describes as a way of addressing marginality through the creation of rhetoric and the employment of props that demonstrate "us against them" mentalities affecting minorities.

Ethnic stand-up became popular as early as the 1920s, with Mort Sahl (1927-1996) and Moms Mabley (1894-1975), and then again with Lenny Bruce (1925-1966) in the 1950s. Moms Mabley was the first female stand-up comedian and ventriloquist in the US. An African American woman, her work addressed both race and gender. Mort Sahl, who is Jewish American, discusses US news and current events in his work; Lenny Bruce addressed antagonism between the Irish and the British, amongst other topics.

Richard Pryor (1940-2005), whom I discuss in more depth later in this article, is especially known for turning the tables on the original form of minstrel stand-up by applying the humor of incongruity (addressed below) to stereotypes of African Americans. His focus on race issues in the US in the 1970s and 1980s set the tone for a common trend among stand-up comedians from other marginalized communities.

Contemporary post-9/11 Muslim and Arab stand-up comedy builds on this long tradition in the Anglo-American sphere of ethnic and racial stand-up comedy by performers from marginalized groups, such as Jewish Americans, African Americans, and, more lately, Asian Americans, as well as feminist or proto-feminist comedy by female comedians. I begin with a review of the major figures and trends in Muslim American comedy since its beginnings in 2003. This is followed by a discussion of certain techniques and approaches that have been used by stand-up comedians to counter predominant and discriminatory perceptions of "Others". These techniques are incongruity, performativity, and everydayness. In each case, I provide examples of employment of the techniques by comedians 
working in the prior traditions, as well as use by contemporary Muslim comedians who are influenced by these approaches. I argue that contemporary Anglo-American Muslim stand-up is a combination of incongruity and performativity, as well as everydayness. Everydayness, as I will explain, is particularly vital to the subversion of stereotypes of Arabs and Muslims in stand-up comedy.

In the last section of this article, I focus in on case studies of British Pakistani Shazi Mirza and Palestinian American Tissa Hami, two of the handful of female Anglo-American Muslim comedians in the scene today, and how they draw on the tradition of "performativity" in ways similar to Jewish American, African American, and Asian American female performers to subvert the stereotype of the veiled and oppressed woman. All Muslim American comedians engaged in stand-up as social critique perform themes relevant to the Arab $=$ Muslim and terrorist stereotypes. Nonetheless, and because they are women, Hami and Mirza also include the "veiled and oppressed woman" stereotype.

\section{Overview of Muslim American Comedy}

This section provides a brief overview of Muslim American stand-up comedy, which technically began with the solo act of Preacher Moss, an African American convert to Islam, called Allah Made Me Funny (Allah Made Me Funny 2003), created two years after 9/11, in 2003. Several studies have argued that Muslim American stand-up began post-9/11 because that is when Muslims in America came into the limelight as a group. In "Muslim Ethnic Comedy: Inversions of Islamophobia", Mucahit Bilici states that "Muslim" comedy existed before 9/11, but the form of comedy known as "Muslim American" comedy only emerged after that tragic event:

Like every other ethnic group, the various Muslim communities had their internal humor, their own comedians. But they were completely obscure from the point of view of the larger society. They lacked both common language with and a reputation among mainstream audiences. Members of comedy troupes such as Allah Made Me Funny and Axis of Evil were comedians, but they were not 'American Muslim' comedians. They were either obscure ethnic comedians or generic mainstream ones. (Bilici 2010)

Preacher Moss hoped that Allah Made Me Funny would educate audiences about the truths of Muslims and non-Muslims' existence in America following 9/11, but also preceding it. The Axis of Evil, The Muslims Are Coming! (The Muslims Are Coming 2013) The New York "Arab-American" Comedy Festival, and Netflix comedy specials Mo Amer (Mo Amer: The Vagabond 2018): The Vagabond and Warn Your Relatives are all examples of what has now developed into a whole genre of Muslim American stand-up comedy, the popularity of which is evident online, on Netflix, YouTube, Vimeo, Twitter, and Imdb, among other digital platforms, as well as offline in live performances across America and beyond. The titles of the various shows and tours deliberately include terminology indicative of Islam at a time when Islamophobia is on the rise. Allah Made Me Funny and The Muslims Are Coming!, for instance, include the words "Allah" and "Muslims", and the 2006 Axis of Evil is a spin on the Bush administration's 2005 label for Iraq, Iran, and North Korea. Indian American Azhar Usman, of Allah Made Me Funny, explains, "The word 'Allah' ... is actually beautiful. And it is nothing more, nothing less than the Arabic word for God. So Allah Made Me Funny is the Muslim answer to God Made Me Funky" (Bilici 2012). Usman has been referred to as "America's Funniest Muslim" and one of the "500 Most Influential Muslims in the World". In the words of Indian American comedian Azhar Usman: "When you study the history of stand-up, you see how often it gets used as a tool, an art form for the underdog. Black American comedians, Jewish-American comedians, Latino comedians, women comedians, gay comedians, blue-collar Americans, Jeff Foxworthy and that whole hillbilly comedy tour ... time and time again, you find that groups that are written off by mainstream America use comedy as a weapon. This is a way for them to speak truth to power-that quintessentially American thing to do. And that's what we're doing as well" (Amarasingam 2010). 
It might seem strange that such a non-humorous event as 9/11 would create an opening for comedy. Nonetheless, writings on this topic argue that the event was a turning point in general for the subversion of Islamophobia by Muslim Americans, and scholars on the topic, such as Bilici, Amarasingam, and Michael, argue that the post-9/11 backlash is the driving force behind the creation of a stand-up that is "Muslim American", per se. Muslim Americans are the most recent minority group in the US to be spotlighted negatively. Orientalist tropes of them did, however, exist before $9 / 11$. They merely metamorphosed into stereotypes of Muslims as "terrorists", as a threat to national security, post-9/11. This caused comedians of different Muslim backgrounds to adapt their stand-up routines to include new themes, contextualizing the humor in their jokes to the new Muslim American situation and to the environment in which they and other Muslims would henceforth live.

Muslim American comedy thus addresses common stereotypes and situations of Arabs and Muslims that intensified post-9/11, including "airport profiling and air traveling, Arab and Muslim alleged anger, terrorism, religious fanaticism, suicide bombing, etc. [in addition to] differences between their ethnic and religious groups". In other words, the post- $9 / 11$ backlash affects people's lives on an everyday basis, and the decision by many comedians to self-identify as Muslim and address that identity in their work is a conscious one in response to those circumstances. As negative stereotypes affect the everyday lives of Arabs and Muslims, performers of stand-up comedy of diverse Muslim backgrounds who were not addressing topics related to being Muslim before 9/11 felt the need to turn to humor relevant to Muslim Americans following the terrorist attack and subsequent backlash. As indicated by the title of Bilici's Finding Mecca in America: How Islam Is Becoming an American Religion, Muslims actually became Muslim American, that is, discovered that identity, post-9/11.

In 2003, Preacher Moss performed his Allah Made Me Funny at a comedy club in Washington, D.C. Preacher Moss, who is also founder of the show The End of Racism (The End of Racism 2012), is "dubbed the 'new Dick Gregory' owing to his artistry, wit and insight into his cultures from around the world". Dick Gregory (1932-2017) was an African American comedian, anti-racist, and vegetarian activist. In 2006, Preacher Moss's Allah Made Me Funny developed into a trio including comedians Indian American Azhar Usman and Palestinian American Mo Amer. Allah Made Me Funny, the troupe, comprises stand-up routines on what it is like being a Muslim in America after 9/11. "The concept of this tour is to make a comprehensive effort to provide effective, significant, and appropriate comedy with an Islamic perspective, which is both mainstream and cross-cultural. The idea is to provide a venue whereby Muslims and non-Muslims can feel safe, relevant, and inclusive of an experience where humor is used to bridge gaps of bias, intolerance, and other social ills that are pre and post 9/11 relevant", explains Preacher Moss (Allah Made Me Funny 2003). It is considered to be the longest-running "Muslim American" comedy tour, lasting from 2003, when the idea was conceived, up until 2011, when it was made into a film.

The year 2003 was also the point that Palestinian Americans Dean Obeidallah and Maysoon Zayid founded The New York Arab-American Comedy Festival (2006), a festival that is taking place virtually this year (2021). The New York Arab-American Comedy Festival brings together Arab American comedians from across the US and was also created with the aim of overturning "negative images and stereotypes of Arab culture in post9/11 America". The festival is specifically "Arab", instead of "Muslim American". There seems to be limited knowledge of the fact there are Arabs who are non-Muslim (chiefly, Christians), and in my opinion, The New York Arab-American Comedy Festival's focus on Arab comedians is an effort at overturning perceptions of Arabs as "evil" but also the perception that "Arab = Muslim", a stereotype that is highlighted by Jack Shaheen (himself an Arab of Christian background) and other critics. One of the performers of Christian background at the festival, for example, is Sammy Obeid. Obeid is the creator of the work Get Funny or Die Tryin (Get Funny or Die Tryin 2013).

In 2006, only one year after the Bush administration coined the phrase "the axis of evil", Egyptian American comedian Ahmed Ahmed created the Axis of Evil Comedy Tour. 
The Axis of Evil Comedy Tour features Ahmed Ahmed, Palestinian American Aron Kader, Iranian American Maz Jobrani, and Palestinian American Dean Obedallah. The comedians say that they hope their work casts Muslims in a more realistic and positive light. Indeed, the Axis of Evil has been described as crossing borders by reaching out to non-Muslim audiences and creating a stronger sense of solidarity between diverse Muslim identities. Jobrani explains the difference between Arabs and Iranians. "I tell my American friends I'm Iranian, and they go, "Oh so you're Arab". And I go, "No, we're different. We're not Arab; but we're similar. We're all getting shot at, that's one thing. But Iranians, ethnically we're White. So stop shooting". And then my American friends go, "Well how can we tell you apart?" And I go, "It's in the accent. Iranians talk a lot slower. Arabs talk a lot faster" (Axis of Evil 2006).

In 2008, PBS released the film Stand Up: Muslim American Comics Come of Age, featuring Ahmed Ahmed, Azhar Usman, Dean Obeidallah, and female comedians Iranian American Tissa Hami and Palestinian American Maysoon Zayid. The objective behind Stand Up: Muslim American Comics Come of Age (Stand Up: Muslim American Comics Come of Age 2009) is to debunk negative images of Muslims post-9/11. The work has been said to "leave no stereotype untouched". Comedians address fear of Muslims by non-Muslims and their own fears as Muslims in a post-9/11 world, where images of them are those of terrorists and threats. "In preparation for an emergency, please take a moment to look around and locate the Muslim nearest you", jokes Hami, in reference to airport security (America at a Crossroads 2007). Ahmed Ahmed says, "For Homeland Security, I try to look like I'm a patriot ... red, white, and blue, the baseball cap and the Adidas. I try to talk American and look American: go to the ticket counter and be like, "Hey! How y'all doin' man?" (America at a Crossroads 2007).

Then, in 2012, Dean Obeidallah and Iranian American Negin Farsad co-created the comedy tour The Muslims Are Coming!, an obvious reference to the cry of Paul Revere who warned against the imminent invasion of the British at the beginning of the American Revolution, the implication being that Americans need to be warned of "invading" Muslims in order not to lose their liberty and country. The irony, of course, is that the show tells the audience that there is no need for alarm at all. The Muslims Are Coming! also deals with stereotypes of Muslims. The Muslims Are Coming! was made into a film documentary in 2013, in which the audience is shown a road tour of Muslim American performers of stand-up in the US and their conversations with locals. With the same goal of addressing Islamophobia, the comedians highlight everyday Muslim Americans. "If you've never had a Muslim friend, this movie is your first Muslim friend, which is cheesy, but we're happy with that, we want that to be the case" (Zimbardo 2014).

In 2018, Indian American Hari Kondabolu created the Netflix special Warn Your Relatives, a title which humorously advises the viewer (and viewer's family) that he is of "Other" background. Kondabolu discusses the racism that his immigrant parents went through in America, claiming that someone told his mother to "wipe that red dot off her face". One of his jokes is about how President Donald Trump's ban on travelers from Muslim-majority countries can be ended by the boy band One Direction, on the condition that they bring back the Muslim singer Zayn Malik, who left to pursue a solo career. "Then they have to plan a worldwide tour, including every major city in the US" (Warn Your Relatives 2018). Banning a whole religious group from America is obviously not a funny thing; Kondabolu deals with the event by ridiculing it in a humorous fashion. In that same year, 2018, Mo Amer released the Netflix comedy special Mo Amer: The Vagabond. As a refugee seeking American citizenship, Amer, who is of Palestinian-Kuwaiti origin, traveled to perform comedy for many years to other countries on a special document for refugees without a passport. After waiting twenty years to obtain citizenship, Amer goes to his American History Immigration Exam. He describes the anxiety that he and Javier, a Latino whom he meets in the waiting room, feel while waiting their turn for the exam, and he highlights Javier's concern at waiting two hours for his turn. Amer goes on to joke about anxiety-inducing questions forming part of the exam. "Have you or anyone else 
you know been involved with or given funds to, from the time period of 1933 to 1945, for the Nazi party?" "Have you or anyone else you know been given funds to a terrorist organization, Mr. Mohammed?" (Warn Your Relatives 2018). In these examples, we see that "Muslim American" stand-up comedy is a genre of comedy that was created after 9/11 as a conscious decision on the part of Muslim American comedians and has been developing rapidly ever since.

The landscape of Anglo-American Muslim stand-up cannot be described without considering the Internet, which has created a space for stand-up comedy in the form of videos, films, and documentaries. Stand-up comedy shows that were only accessible in-person are now easily recorded and put online. The fact that much of the material is free also makes it more accessible. The worldwide popularity of Anglo-American Muslim standup comedy aimed at addressing stereotypes is therefore partly attributable to its digital landscape, to mainstream media, and to the fact that comedians own their own websites and do their own promoting on networking sites such as MySpace, Twitter, YouTube, Facebook, and Instagram. Videos of Muslim comedians in the diaspora, as facilitated by technology and cyberspace, have thus been informing social perceptions by responding to stereotypes such as evil terrorist, Arab $=$ Muslim, and the veiled and oppressed woman .

\section{The Backgrounds of Muslim American Comedians}

Comedians working in what may now be called a genre of Muslim American comedy have diverse backgrounds. Comedians interviewed on whether they are Muslim mostly stated that they identify with Islam because they are of Muslim background. This was the response of a group of comedians, some practicing and some not, interviewed on the subject. Dean Obeidallah explained in the interview that he was raised mostly Christian, but that he had learned about Islam from his Muslim father. Palestinian American Aron Kader explained that he has one parent who is Mormon, and one who is Muslim. Jobrani and Ahmed said that they were raised Muslim, as did Ramy Youssef, who featured in The Late Show with Stephen Colbert in 2017. The comedian also performed in the 2019 HBO comedy special Feelings and plays the character Ramy in Hulu series Ramy. Concerning fear of Muslims encouraged by the media, Youssef jokes: "Have you guys seen our show? ... Fox News or any of the news, really. They are all about us. I get why people are afraid of Muslims. Even if I watch for too long, I'm like, whoa" (Willett and Willett 2019). Youssef both acknowledges the widespread fear of Muslims by non-Muslims and invites Muslims to put themselves in the shoes of non-Muslims by "seeing themselves" as they are seen by viewers in a mainstream media that continues disseminating negative images of them.

To demonstrate the diversity of Muslims and Muslim Americans, one of Azhar Usman's jokes includes saying "Salaam" in African American, Arab, Latino, White "new Caucasian Convert", and Indian accents, "because truthfully, I believe you can tell how diverse the American Muslim community is just by listening to the way people say Salaam" (Allah Made Me Funny 2003). Usman also performs for the South Asian ensemble Make Chai Not War (2012).

These diverse backgrounds enable many different types of jokes; Muslim American comedy is far from monotonous. Preacher Moss recounts his conversion to Islam and his Christian parents' reaction, which was to take him to Church. "I walked into the church and everybody knew I was Muslim, even the old ladies. I was like 'Hey, Mrs. Johnson!' and she was like [making a feminine voice] 'Hi, Satan!' [To the audience] You know is bad when you walk through and a whole choir is singing about you! [Singing and clapping like in black gospel music] 'Jesus help this fool 'cause his going to hell! Jesus help this fool 'cause his going to hell! [In high pitch, like a background singer] Heeeeeell! [Back to the previous pitch] Jesus help this fool 'cause his going toooooooo hell'" (Bilici 2010).

Individual Muslim American comedians performed before 9/11, but their performances did not focus on religion. Generic and non-religious themes shaped their performances. "Muslim American stand-up comedy", as such, involving themes such as "flying while Muslim" only began to take shape after the tragic event and the increased 
stereotyping of Muslims as a collective that followed. Before 9/11, Preacher Moss's show The End of Racism had existed for over twenty years, and the comedian was producing stand-up for African American audiences and writing for Hispanic American comedian George Lopez and Jewish American Darrell Hammond in 1995. His work did not focus on Islam and on being Muslim American as it does presently. Similarly, in 1999, Mo Amer won Houston's Funniest Person Contest, a contest involving general, non-religious themes that have nothing to do with perceptions of Muslims. It was only after 9/11 that Preacher Moss created the Allah Made Me Funny comedy tour, as well as the Islamic Scholarship Fund for film and documentary makers seeking to make their voices heard.

Obeidallah began performing generic stand-up in the late 1990s. After 9/11, however, he founded the "Arab-American" Comedy Festival and began to purposely refer to his Arab last name in his performances. "My last name is Obeidallah, I know many people here can relate to this, for the non-Middle Eastern people, do you know what it's like being of Arab heritage with a Muslim last name living in America the last few years? I could use a hug". Obeidallah says that after 9/11, "I thought to myself maybe I can be a comedy ambassador and introduce America to my culture" (Omidvar and Richards 2014).

Comedian Ahmed Ahmed switched careers from acting to stand-up because he was sick, he says, of being typecast as "terrorist \#4" (Zimbardo 2014). Usman changed careers from law. Tissa Hammi switched from Wall Street, and to counter stereotypes of Muslim women, she purposely uses a veil in her performances, as does British Pakistani Shazia Mirza, who has used the opening line: "Hi my name is Shazia Mirza, or at least that's what it says on my pilot's license" (Mirza 2017).

\section{4. "Muslim American" Is the "New Black"}

The increase in the collective stereotyping of Arabs and Muslims post-9/11 is connected to a longer history of marginalization of Blacks in the US. Just as the civil rights movement influenced African American stand-up comedy, Anglo-American Muslim standup comedy was born and became a full-fledged genre after the unfair and discriminatory collective backlash following the events of 9/11. The discrimination faced by Muslim Americans may not be of the same type and degree as the discrimination experienced by African Americans. Nevertheless, Islamophobia is a form of marginalization stemming from racialized stereotypes revolving around religion and appearance. Hence, Muslim American comedians challenge common social perceptions in the context of civil rights by establishing the fact that the group they are speaking of is stereotyped. Post-civil rights era performers continue the legacy against racial discrimination in the form of popular culture, with the understanding that the term "Black" is used in reference to the common experience of racism and marginalization across different ethnic communities. In terms of stereotypes of Muslims post-9/11, Muslim American stand-up represents Muslims as Americans, who, like African Americans, form part of a racial, gendered, and religious imagination. As such, the Black Arts Movement, which is centered on social justice, is a suitable source of inspiration for Muslim American stand-up, a genre of stand-up inspired by racial and religious discrimination. Focusing on being Muslim and on being a minority is the main preoccupation of artists in the civil rights movement and the Black Arts Movement. Thus, Preacher Moss says: "Muslims, here's the scoop. Haters have been around for years and believe me, the same people that hate Muslims hated Asians, hated Latinos, hated blacks, hated Jews ... I'm African-American and Muslim. The United States is scared of two things: black people and Muslims" (Omidvar and Richards 2014). African Americans have been prominent creators of and participants in popular culture, including stand-up comedy. The association of Muslim stand-up with African American culture is a powerful expression of solidarity and advocacy for freedom of religion.

Arabs/Muslims are said to be "blackwashed", that is, considered to be a social problem and a source of social anxiety as Black people are (Schmidt 2014). The religious framing of the Arab as Muslim overrides the importance of differences between religion and ethnicity; the fact that Arabs are not always Muslim, and that there are Arabs of different races 
and colors, as well as Muslims of different races, is not often acknowledged. A conscious decision made by stand-up comedians to focus their humor on Islam suggests using the platform for social change to affect opinions of both the tragic events of $9 / 11$ and the intensification of stereotypes that followed. Encompassing Muslim American humor, also referred to as "brown humor", Muslim stand-up is a collective effort by comedians of Muslim background aimed at reaching wide audiences to address Islamophobia, a social issue that affects Muslims and their communities on an everyday basis. Referring to the vilification of Islam as a "narrow-minded view of a religion", African American comedian Dave Chappelle, who does not perform humor that is relevant to religion, decided to share how he converted to Islam at age seventeen and to comment on Islam being "a beautiful religion" (Chapelle 2020). In terms of his level of religiosity, he says that he is "not particularly good at it". I note Chappelle's comment to point out that, since Islamophobia is such a widespread social issue, a comedian who has been a Muslim without ever having felt the need to mention it before decided to bring it up at an interview after negative stereotypes of Muslims increased. An African American, Chappelle is familiar with the historical problem of marginalization and racialization of groups of people in America.

Similarly pointing out the different ways minorities are viewed and treated, Indian American Hari Kondabolu says that "there is such a high bar to prove something is a hate crime ... Did they say a racial slur? Can you prove its intent? Was there a video recording or was there a white witness-you know, an eye whiteness? Was whiteness present at the time? ... Terrorism, on the other hand, has a very low bar". The comedian then goes on to explain, in his 2018 Netflix special Warn Your Relatives, the difference between how White people and Muslims are perceived by pointing out that if "a white dude did the shooting, that's mental health issues" (Allah Made Me Funny 2003).

Once persons are defined as Muslim or Arab, they are racialized, and the comedians recognize this. Obeidallah repeatedly reminds the audience that he is half Palestinian: "I always tell people I'm not white now anymore. And they go: 'well you look white'. I understand. But white to me in America is not skin color. It's status, it's the way you're treated in society" (Chapelle 2020). Therefore, to demonstrate his opposition to racism, and to demonstrate solidarity with the underdog, Obeidallah began to take Arabic lessons and to publicly identify as Palestinian instead of as White.

Referencing how Arabs have become "the new Blacks", Obeidallah jokes that the "coolness" implied behind being Black makes the stereotype of the Arab/Muslim "terrorist" better. "Sure, we are police targets", but "oh my God, we're cool", so now "white kids in the suburbs" will "start act'n Arab with their friends, dressing Arab, wearing like traditional Arab headdress, tilted to the side to be cool, open shirt, gold chain, smelling like lamb" (Chapelle 2020). In other words, although African Americans are stereotyped negatively as thugs and as a "social problem to be dealt with", the fact that they are front-runners and trendsetters in popular culture has also earned them the "cool" label as a group, and by being compared to Blacks, Arab Americans are also, it is implied, "cool", despite the stereotype of terrorist. In the same way that Blackness is extended to Muslimness by Preacher Moss and Dave Chappelle, Obeidallah's redefinition of Muslimness extends its meaning to that of coolness as associated with Blackness.

\section{Critical Reception}

Comedians countering Islamophobia have been creating a space for non-Muslim viewers to form new understandings that place Muslims in alternate social and cultural contexts by highlighting the increasing social anxiety channeled toward Muslims and by addressing the Arab = Muslim, evil terrorist, and veiled and voiceless woman stereotypes. Due to world events, fear of the ethno-racialized Muslim passenger and the veil have become everyday topics that both Muslims and non-Muslims are familiar with, and in terms of critical reception, non-Muslim viewers have commended performers for their humor. Jobrani says that "When we did the Axis of Evil Comedy tour... what's funny is, I went online to see what people were saying about the show, and I ended up on Sean 
Hannity's chat room, and one guy had written another guy, he said 'I never knew these people laughed', and if you think about it, you never see Middle Easterners laughing in American film or television, you know, maybe like an evil 'I will kill you in the name of Allah' (laugh), but never you know like a 'ha ha ha ha', so just that in itself, to have people realize that, that in itself is, I think, a little bit of progress" (Zimbardo 2014).

Muslims are a part of the intended audience for Muslim stand-up comedy, and the reaction by Muslims to this body of work has also been mostly positive. Muslim viewers are supportive of Muslim American stand-up comedians and "also grateful to them for painting a new image of their faith ... Muslim standup comedians are playing a role in breaking down cultural barriers, promoting inter-religious and inter-cultural dialogue, as well as tackling the misperceptions about Muslim and Arab Americans in the United States".

Jokes by and about an ethnic group are appreciated by members of that group because they constitute an insider knowledge that few comedians who are not from that group possess. This insider knowledge permits the audience to identify with and relate to the comedian; there is a thrill, you might say, in recognizing oneself in a public representation in a humorous and thus positive way and feeling that others might appreciate the representation. Most or all of the jokes play this role, but examples are nevertheless instructive. Ramy Youssef, for example, says that he wishes Muslims prayed on Sundays. A non-Muslim audience may be familiar with the fact that Friday prayer is a big deal for practicing Muslims. What the non-Muslim viewer may not have considered, however, is how tricky that can be in terms of scheduling and how that balances out with being an American with Friday plans after a long week at work. Christians do not have that problem because they go to Church on Sunday, a day that precedes the start of a new workweek rather than celebrating its end. This is a dilemma a Muslim American audience would not hear about from a comedian with a non-Muslim background. Another example of a joke from an insider's perspective that Muslim viewers can relate to is: "I think all Muslim people do this: You ever been watching television or a movie ... at the end they start rolling the credits ... suddenly you see a Muslim name. You get so excited! Saliiiiiim! Oh my God! His name is Salim!"' (Usman 2008). Usman's point on the limited representation of Muslims involved in the film industry is a valid one that may have not crossed a non-Muslim's mind.

A 2015 case study of college students of Muslim backgrounds claimed that the comedians speak to Muslim Americans through jokes in a way that allows them to "see themselves", and to appreciate their upbringings, ethnic backgrounds, and religion, and their perceptions of stereotypes of Muslims. Axis of Evil humor, for example, includes jokes about prayer, drinking alcohol, and eating pork. Comedian Aron Kader says that his father used to have to bribe him to learn chapters from the Koran, and in Allah Made Me Funny, Mo Amer stops mid-joke to pray. The Muslim interviewees indicated that they identified with the jokes related to them, particularly the one concerning pork that dealt with the fact that many Muslims commit sins such as drinking alcohol but will not commit the sin of eating pork. Muslim interviewees could also relate to jokes on perceptions of and lack of knowledge on Muslims by non-Muslims, such as Obeidallah's joke "Oh you're Arab, but you look so nice! ... Oh you're Arab, what a coincidence, I love Indian food" (Allah Made Me Funny 2003).

With regard to female Muslim comedians, Muslim viewers highlighted Maysoon Zayid's jokes about marriage, for example, when she says that a 33-year-old in American years is actually 67 years old in Arab years for a woman, implying that she is too old for marriage. Covered-up Shazia Mirza says, "Muslim men won't marry me because I speak" (Mirza 2017), implicitly making fun of the stereotype of the "veiled and voiceless" woman. Mirza and Hami both incorporate veils and hijabs in their performances, and female Muslim viewers and interviewees who wear the hijab say that they particularly identify with the two comedians, referring to their work as "a whole new genre of standup" that Muslim women can relate to. Arguing that the incorporation of the veil and headscarf in stand-up contributes to a sense of normalcy by challenging stereotypes of 
Muslim women, one hijabi interviewee stated, "It's just like if someone was wearing a suit like-I guess it's nice to see that cuz it kind of gives a different portrayal like it breaks stereotypes of you know the hijabi Muslim, she doesn't talk she doesn't do like anything. She just does-like she's the oppressed but she's doing-she's acting like a normal person you know? So I guess-it, it helps in the image of Muslim women". "I feel like people alienate Muslim women who wear hijab", said another interviewee, "like okay, she's a foreigner, she's oppressed, or she doesn't know what she wants. She's being told what to do kind of thing. And here she is, she's wearing it she's a comedian. So I think it helps break that image of that mindset people have of Muslim women, especially those wearing the hijab" (Hussain 2015). In other words, Muslim viewers are accustomed to veiled and hijabi women's engagement in all types of careers, and because the stereotype of the veiled and voiceless woman is one of the most popular stereotypes of Muslims, comic subversion of the image is appreciated not only by female but also by male Muslim viewers.

Asked about female comedians wearing the hijab, a male interviewee remarked: "It's not an issue for a woman to wear a hijab and do any profession ... I think it actually helps break stereotypes in my opinion you know. To people who see Muslims as very uptight people you know and they don't really see Muslims right? It shows the diversity of Muslims you know? It shows here's the Islam but Islam doesn't mean a bunch of very strict people ... Some people are not so strict, some people are very strict" (Hussain 2015).

However, a couple of interviewees in the study mentioned that it is acceptable to employ the veil and hijab in stand-up as long as performers are aware that they are representing the Muslim community. "She (the performer) should like also be aware of like she carries a heavier role in what people will think of Islam. People notice that she's a Muslim and they'll be like extra sensitive to the things she says ... As opposed to like someone - a random person wearing a hijab it would be a big deal since more people know her. There's always going to be people looking for like something to like pick on kind of" (Hussain 2015). Here is a suggestion that there are limits to dealing with religion, or at least Islam, in comedy. In fact, while both Tissa Hami and Shazia Mirza use the veil and hijab in their performances, some reactions to Mirza in particular have been negative. She has both received hate mail from male Muslim viewers and been verbally and physically attacked during performances because of the sexual nature of some of her jokes.

Nonetheless, overall, Anglo-American Muslim comedians continue to be supported by the majority of Muslims who understand and identify with jokes that include an insider's perspective. Support continues during the COVID crisis, with viewers going online to attend shows. For instance, in 2020, the Concordia Forum at Concordia University in Montréal, Canada, hosted The Socially Distant Eid Comedy Night (The Socially Distant Eid Comedy Night 2020), which brought together approximately forty performers of Muslim background with the aim of "lifting the spirits" of Muslims who could not gather with family during Ramadan and Eid because of COVID. At this event, Canadian Muslim comedian Salma Hindy humorously pointed out the similarities between COVID precautionary measures, such as covering one's face, maintaining one's distance, and washing one's hands, to Shari'a law.

\section{Comedic Techniques}

Comedy that aspires to reveal and reverse stereotypes involves more than "making jokes". It is a subtle and highly skilled art that requires the conscious use of techniques. I argue that three techniques figure prominently in contemporary Anglo-American Muslim stand-up: incongruity, performativity, and everydayness. As we saw above, Muslim American comedians follow in a tradition of using this type of popular culture to present their own worlds and concerns. Thus, in each case, I provide examples of employment of these techniques by previous comedians from other marginalized groups, such as Jewish Americans and African Americans, as well as examples by contemporary Muslim comedians who take them up. 
Before proceeding to the three techniques, it will be useful to define and discuss superiority humor. I introduce it because Muslim American comedians do not employ abjection humor, which is related to superiority humor (see below), because superiority humor has long been used against Muslims and Arabs. Thus, they recognize that some persons, including even perhaps members of their audiences, consider Muslims inferior or strange (and themselves superior and "normal") and set out to undermine that attitude. In other words, Muslim American comedy rejects and moves beyond superiority humor.

Superiority humor has a long history. Plato, for instance, wisely observed that laughter at others indicates ignorance of others. O.J. Double traces superiority humor through philosophers such as Aristotle, Cicero, and Hobbes, who explained that perceived flaws in other people make one feel superior or better about oneself, thus causing one to laugh Rhetoricians Quintilian and William Hazlitt are amongst many critics of superiority who perceive it to be hostility and derision disguised as humor, while the ethnologist Konrad Lorenz argues that the technique is instinctively aggressive. "This is the essence of 'putdown' humor", writes communications professor Joanne Gilbert. "Putting the 'object' or butt of a joke 'down' raises the subject or teller of the joke 'up'" (Gilbert 1997).

In the case of superiority humor specifically aimed at minority groups, Hungarian British novelist and journalist Arthur Koestler (d. 1983) (Double 1991) argued that it reflects an instinctive dislike by the comedian of "physical or mental malformations" on the part of the comedian as well as on the part of the audience which finds the jokes funny. He explains that "a joke is funny if it esteems a group to which the individual belongs, or a group with which the individual identifies (a 'Reference Group'); similarly, it will not be found funny if it disparages a group to which the individual belongs, or a group taken as a reference group by the individual" (Double 1991). Whether one finds jokes that use superiority humor aimed at minorities to be funny is relative. If a joke puts down a group the audience dislikes, does not know well, or cannot relate to, the viewer perceives that joke to be funny. However, if the joke puts down the viewer's own community, they will see the joke as hostile or as racist. Superiority humor evidently does not allow all spectators to take part in the laughter.

John Limon identifies a type of humor common in American standup from the 1960s forward that he calls "abjection". Limon's theory is complex, but the aspect that is useful for our discussion here concerns the relation of abjection to superiority humor. Abjection is related to superiority but includes self-deprecation. Limon believes that much of American stand-up in its heyday in the mid-twentieth century depended on abjection and provides examples from male comedians of Jewish background, who dominated stand-up at that time. These artists performed Jewish stereotypes in their routines, for instance, by parodying Yiddish accents. Not all viewers, however, get the joke of abjection humor. Some continue to understand superiority, rather than realizing that the stereotype is being subtly undermined. Although comics argue that they make fun of everyone and everything, abjection does not work for everyone in the audience (or at least a diverse audience). As Willett and Willett stated, "Those who do not share the comic's perspective may find the humor offensive and fuel for their own outrage, or they may miss the irony entirely" (Willett and Willett 2019). Abjection humor thus does not necessarily result in the subversion of stereotypes. Most seriously, abjection risks insulting parts of the audience: the targeted group as well as "politically correct" spectators, since it continues to contain some measure of objectification and subjectivity (a term used by scholars of humor to refer to jokes that speak to one audience only by putting others down), as well as aggressivity. This is important to note because it is precisely the absence of objectification and subjectivity in incongruity humor, which I discuss in more depth in the next section, that gives it its ability to establish a "known" platform (that is, a common understanding) upon which the entire audience can "get" a joke.

Nevertheless, it should be acknowledged that some scholars of popular culture have deemed abjection humor, with its element of put-down, essential to both ethnic and feminist stand-up. As Joanne Gilbert puts it: "Many critics of humor seem to forget that 
they are analyzing jokes-humorous discourse that reminds the audience not to take it (or themselves) seriously with every punchline. Indeed, humor is a rhetoric unique in its ability to undermine its own power with the "only joking" disclaimer. Critics, especially those most adamantly opposed to self-deprecatory humor, however, appear to overlook that fact that these are the jokes, folks!" (Gilbert 1997). This does not, however, appear to be the view of diasporic Muslim and Arab comedians working in the Anglo-American sphere. I would contend that their avoidance of "abjection" actually contributes substantially to their success.

\section{Incongruity}

Incongruity is a form of humor that demonstrates how common presumptions about a targeted group are "inappropriate, absurd, or inverted". This is accomplished through a process that involves the collision of frames of reference amongst spectators, the concept of incongruity itself involving making frames of reference, or patterns of thought, collide. Incongruity and its sometimes humorous effects are a subject that has long been discussed, by figures such as philosopher Francis Bacon (d. 1626), Thomas Hobbes (d. 1679), Francis Hutcheson (d. 1746), David Hartley (d. 1757), James Beattie (d. 1803), Soren Kierkegaard (d. 1855), Arthur Schopenhauer (d. 1860), and Arthur Koestler (d. 1983) (Double 1991). Incongruity, it is argued, is the most subversive form of humor, since it plays with the social and cultural contexts of both the minority and majority, so that jokes that employ it can succeed in getting spectators to identify with both the comedian and the target of the joke. Incongruity is, above all, an inclusive form of humor, which requires the artist to be cognizant of and deploy knowledge of the cultural contexts of an audience. What is considered humorously incongruent in one country, era, age group, ethnic population, etc., depends on how it plays off that particular culture and context and is likely to be not funny or even incomprehensible to others.

Incongruity, as explained above, consists of making frames of reference, or patterns of thought, collide. Thus, the success of each joke relies on deviation from what is perceived as "normal" or expected. Without understanding of the context in which both the humor and performance take place, there is no guarantee that the incongruity, unexpectedness, absurdity, or clash of concepts that makes audiences laugh will occur. The clashing of concepts in incongruity only happens when the artist understands what is normal. In other words, to point out an absurdity of a stereotype, comedians need to know what the audience will consider incongruous or absurd. Acknowledging what is "normal" and "abnormal" at the beginning of a joke hence guarantees that its absurdity will clearly shine through and have the desired effect.

Starting with common knowledge, jokes employing incongruity make a point through a shared ground upon which an experiential understanding with an audience can take place. This common ground is then combined with autobiography. "Frames", or windows, through which spectators understand a joke or film, are created through already existing patterns of thought. Framing is widely employed by creators of media content and writers of autobiographies for explaining complex topics. By drawing on pre-existing patterns of thought, framing reduces the complexity of a topic, which permits audiences to process information more easily, and the understanding that results from the simplification of a topic is argued to, in turn, alter cognitive frames and perceptions.

Jokes employing incongruity are based on the premise that absurdity and juxtaposition of words and ideas drawing on pre-existing knowledge make people laugh. Framing an incongruous joke in this way depends on three elements: a shared common knowledge; absurdity; and autobiography. I discuss everydayness as an important characteristic of autobiography in a subsequent section. What is important to note here is that the aim behind incongruity humor is to demonstrate that new collective knowledge and understanding of where the stereotype comes from are stronger than illogical fear, and that this new understanding can cause an alteration in social perceptions. A mismatch of concepts, language, or logic recognized through a shared knowledge results in a collision 
of "frames of reference", "associative contexts", "types of logic", "codes of behaviour", or "universes of discourse" (Zimbardo 2014), and such collisions only occur when social and cultural notions of "normal" and "abnormal" are taken into account.

According to Limon, Richard Pryor (1940-2005), an African American, was the first stand-up comedian to apply the humor of incongruity to the topic of race. Comedians from minority groups are able to immediately perceive deviations from common sense in stereotypes because they are underdogs amongst the majority themselves. This type of insight is shaped by both insider and outsider knowledge, meaning that the comedian is able to speak to a minority group while explaining minority life to the majority group. Pryor demonstrated close familiarity with not only Black but also White culture; familiarity with the majority culture is, in fact, needed by minorities to function and survive. Pryor did not use what Limon terms abjection humor because he came from an "abjected" race himself. He used the humor of incongruity instead. With both Black and White spectators in the audience, his performances involved wearing a cap that is half black and half white. As Limon puts it, rather than employing abjection, Pryor's work "pollutes all distinctions between the dead and the living, whites and blacks, prehistory and modernity, the vertical and the horizontal". Limon illustrates his point with the following comedic bit:

Look at the white people rushing back! This is the fun part for me when the white people coming back after the intermission find that niggers stole their seats. [One of Pryor's white voices, nasal:] 'Weren't we sitting there, dear?' [Black gangster voice:] 'Well, you ain't sittin' here now, motherfucker (Limon 2000).

By presenting both Black and White characters in his routine and by drawing on a racist cliché of Black lawlessness, Pryor mocks societal White privileges, such as getting the best seats in a show. By imagining Blacks taking the good seats from Whites, he creates a scenario in which racial roles are reversed. Framing a scenario in which racial roles are reversed by drawing on shared knowledge of inequalities as seen or experienced on a daily basis in American society is a tactic that enables spectators from both minority and majority groups to see the absurdity of racism.

Continuing a historical tradition of subverting stereotypes through stand-up, Muslim American comedians are the most recent ethnic group explaining what it means to be a minority by pointing out irrationalities in stereotypes through deviation from what is perceived as "normal" or expected. Stressing differences between the perceived Muslim and the "real" Muslim on stage, comedians fully familiar with both American and Muslim cultures address both Muslim and non-Muslim audiences. Anecdotes from a marginalized minority reiterate the absurdity of stereotypes as addressed by other minorities in the past, and comedians' insider knowledge enables them to share experiences as "Otherized" Muslims self-positioning themselves in ways that offer audiences new insights. Of course, this also involves actively building "common knowledge" by informing audiences about aspects of Islam and Muslim life, which they are more likely to be unfamiliar with than with Black culture, a point humorously brought home by Azhar Usman in the Allah Made Me Funny comedy tour: "We gotta do a better job in explaining ourselves. Do you ever think about how ridiculous you sound when you go to your boss to ask for a day off for Eid but you don't know which day it is?" (Allah Made Me Funny 2003).

In "Muslim Ethnic Comedy: Inversions of Islamophobia", Mucahit Bilici also observes that there is, overall, a lack of "common sense" on the part of the non-Muslim majority, that is, a social consensus and social vision shared with the Muslim (or Arab) minority. The Anglo-American public, as suggested in the previous paragraph, is not very familiar with Islam and the life of Muslims or Arabs. How, then, can one find the shared understanding or platform that is necessary to deploy incongruity? Willett and Willett suggest, and Bilici at least implies, that common ground is found in fear; this is something the majority, nonMuslim, and non-Arab audience immediately recognizes. Therefore, Muslim American comedians frame their work in a way that strategically shares culturally determined fears in a post-9/11 climate and then proceed to point out the absurdity of stereotypes by making viewers' frames of reference collide. The comedians establish common ground more surely 
by letting it be known that they themselves experience fear in such situations: explicitly, fear of being mistaken for a terrorist, but also implicitly (reading between the lines of such jokes), actual fear of terrorism.

Incongruity is an ideal approach to subversion of stereotypes in the case of Muslim stand-up artists since it is aimed at establishing a new collective understanding of where a stereotype comes from that is stronger (so the artists hope) than the illogical fear initially presented. When recognizable social attributes given to a group of people-Muslims, for example-clash with a stereotype (in this case, the Muslim Arab terrorist), the audience perceives the absurdity that the comedian is attempting to point out. Muslim stand-up artists begin by drawing on "social signification", or common stereotypes, to ensure that everyone is on the same page. Then, as the "Other" standing immediately before the audience on stage, they offer different perspectives by emphasizing the lack of common sense in stereotypes, and in this way, spectators are put in a position in which they question their own patterns of thoughts and assumptions about the stereotyped group.

To re-cap the workings of incongruity before proceeding to additional examples: a joke is only effective if the audience can understand it and relate to it at some level. This is why incongruity requires knowledge of the audience's culture and patterns of thinking. Enabled, in their own culturally hybrid position, by their knowledge of not only Muslim American but also American culture, Muslim American stand-up artists are able to speak to both audiences simultaneously. Stand-up humor drawing on a long history of American marginalization of minority groups is thus used to address both insider and outsider audiences. Offering understandings of both the majority view and that of the underdog, the use of incongruity humor in Muslim American stand-up comedy reveals the illogic and actual absurdity of stereotypes. Thus, thanks to its cultural contextualization, the humor of incongruity is a form of social communication that reaches wider and more diverse audiences than abjection humor.

Dean Obeidallah acknowledges his own subversive use of incongruity (which he calls "absurdity"), explaining that "subverting is what comedy does ... I think there's a lot of absurdity inherent in the assumptions people make, which makes it easy to make jokes about-through naming it or claiming it". Describing his employment of the technique, Obeidallah says: "For me to get up on stage and be like "I'm Muslim, so look out!" you know, it's ridiculous, playing with hyperbole ... Comedians are in a great position to reveal a lot of that absurdity ... I mean humanize is such a tricky word because obviously (laughter) I think it does allow people to see Muslims as people rather than as stereotypes (Amarasingam 2010). In more technical terms, Obeidallah tells how Muslim American stand-up comedy employs, with great effect, a strategy of framing that makes patterns of thought collide in order to reverse stereotypical thinking and to establish what Bilici calls "common sense".

A joke about Americans by British Pakistani comedian Shazia Mirza provides an illustration of the comedic technique of incongruity (or absurdity) described by Obeidallah. Mirza begins the joke by presenting a piece of information that both American and nonAmerican audiences are aware of. She plays on the common perception of Americans as lacking in knowledge of geography and other countries and cultures. "An American told me, "When are you going back to India, Paki?" Now, I know the Americans are bad at geography, but that is taking the piss. I started talking to her, and she said, "I know what you mean. I used to live in Islam once"'" (Mirza 2017). By presenting the American character as confused about whether Islam is a religion or a place and unaware that there is a difference between India and Pakistan, Mirza does three things. First, she establishes a common ground with her audience by acknowledging the limited importance supposedly assigned by the average American to other countries; second, she highlights the lack of "common sense" in the question and comment; and third, she vividly expresses, using language that is a bit humorous, her own frustration as a Pakistani visiting America: "I know the Americans are bad at geography, but that is taking the piss". India and Pakistan have a very long on-going conflict (over Kashmir); therefore, to a Pakistani like herself, 
confusion between India and Pakistan is absurd, similar to the absurdity that an American would see in confusion between Connecticut and California. The "new knowledge" that is communicated here is that Muslims are particular people in particular locations, rather than one undifferentiated mass.

Drawing on her experiences traveling in the post-9/11 era, Mirza brings our attention to another absurdity: not wanting to be seated near a Muslim woman on a plane. The common ground or platform here, as explained above, is fear. Added to this is the stereotype of a veiled Muslim woman, who is presented in popular culture not only as oppressed but also frightening because she is associated with the culture from which terrorists emerge. "Sitting three rows behind a "terrorist" does not make you any safer" (Mirza 2017) is Mirza's "reality check" to her audience. The hope behind incongruity humor is that common sense is stronger than illogical fear.

Similar to Pryor's deployment of the humor of incongruity by playing on differences between White and Black people in America, Anglo-American Muslim comedians often use differences between "Whites" and Muslims in their routines. Muslims are evidently not a racial group, but they are often regarded as such, so the comedians are able to begin with that common platform, which the audience is already familiar with through the work of African American stand-up artists. Dean Obeidallah jokes: "There's a difference between us and white people. White people never suffer as a group when a few people do something bad in their group. Middle-Eastern people do. And honestly, white people ... let's be honest, you have a fair share of bad things: corporate scandals, President assassination, NASCAR, Paris Hilton, country music ... That is audio terrorism to me" (Axis of Evil 2006). By juxtaposing post-9/11 Islamophobia with well-known symbolic artifacts of American popular culture, Obeidallah speaks to both Muslim American and non-Muslim American audiences. The non-Muslim audience readily understands the ridiculousness of Hilton, country music, etc., as terrorism inflicted by Americans and may consequently realize the ridiculousness of considering all Muslims to be terrorists.

As the more evidently White son of Muslim converts, Ahamed Weinberg plays on race in a different way, by showing the absurdity of racialization of Muslims itself. The shared platform with the audience is that he is White, as well as (going back to Pryor) the now widely recognized truth that Whites are privileged. "I'm a White Muslim. It's an interesting reality. First of all, my name is Ahamed not Mohammed, which is more confusing, I know ... If I looked Muslim, my life would be much harder. But I'm White, and it's great. I think that's the secret. If you wanna be Muslim, just be white, have red hair, and make sure your last name is Weinberg. Being White is an advantage. It's like having a motorcycle in the traffic jam of races" (Weinberg 2019).

\section{Performativity}

Judith Butler famously proposed that the repetition of individual and collective acts constitutes the concepts of femininity and masculinity and grounds identity in social temporality. According to Butler, definitions of the body are cultural constructions consisting of how one acts or performs. "The gendered body", Butler writes, "acts its part in a culturally restricted corporeal space and enacts interpretations within the confines of already existing directives" (Butler 1988). Butler's concept of performativity is useful for the study of standup comedy. Stand-up is an "act", and a theatrical one at that, which reflects individual and collective experiences that constitute social reality through language, mannerisms, and other symbolic artifacts. The interpretation of acts in society may be compared to the interpretation of scripts in stand-up and other types of theatrical performances. For instance, drag artists (an example given by Butler herself) use performativity to challenge concepts of masculinity, relay novel understandings of gender, and re-define identities.

Butler's attention to the ways norms may be displaced by performing them in a different way is crucial to the analysis here. In Butler's telling, notions of gender are continuously created and re-created, and perceptions of the body are culturally perceived and determined through repeated acts relevant to gendered existence. Nonetheless, if these 
acts are performed and/or repeated in another way through other channels, socially or culturally construed definitions are subverted. Drawing on the familiar, or on pre-existing knowledge, stand-up artists therefore write and re-write comedic scripts to offer new meanings of their identities.

Performativity has been a useful tool for feminist comedians. With a career in stand-up that began in the 1960s, Jewish American Joan Rivers (Akin 2016), for instance, employed performativity by engaging her audiences through a linguistic framing that is conversational. Rivers used repetition of certain expressions such as "look at that person", "C'mon", "I'm so glad", and "Am I wrong?" to communicate immigrant Jewish American identities and feminist issues such as aging, parenthood, and self-image. Her conversational style of performativity, which Adetunji characterizes as "addressivity", created a space for her spectators to partake in her routine by, for example, "looking at that person". Rivers performed (in Butler's term, repeated and re-enacted) a well-known aspect of femininity, that of the catty woman, the "bitch", but as she repeated that act, she subverted it by making it into truthful telling while gradually drawing the audience into that truth.

The work of African American Whoopi Goldberg provides another example. Goldberg performs being Black and female by embodying different characters in her stand-up routines. In her 1985 one-woman show Whoopi Goldberg: Direct from Broadway (Whoopi Goldberg: Direct from Broadway 1985), she plays "Fontaine", the "Junkie", the "Surfer Chick", the "Little Girl", the "Jamaican Woman", and "the Cripple". Each of these characters represents a stereotype of African American femininity that Goldberg repeats but subtly subverts through exaggeration (somewhat similar to drag performance) and putting it in a different context, i.e., in a performance, expected to be funny, by a Black woman recognized to have some wisdom. Using performativity where both Blackness and femaleness are involved is a delicate operation, given prejudice against African Americans, and African American female stand-up artists are said to write their comedy scripts with Black feminist writers such as Alice Walker and Patricia Hill Collins in mind in order to facilitate performing the experience of being both Black and a woman.

Paula Poundstone's 1995 HBO Harvard performance includes using a stool as a prop in order to initiate a conversation with her audience on what to do with her body. Should she stand behind or in front of her stool? Should she sit on it? If so, which leg goes on what rung? A tactic common amongst female comedians, playing dumb is one way of ensuring that the men in the audience are not too offended. Poundstone performs the dumb female, her performance being "at once a reenactment and re-experiencing of a set of meanings already socially established". However, she does it "in a different manner, designed to alter to undermine it" (Butler 1988). She enacts the dumb female in a different way by evidently exaggerating it, using the same stool throughout her performance to behave as if she has no idea what to do with her own body. As that act is repeated in different, increasingly exaggerated ways, the socially established meaning is undermined. In this and the previous example, we see that stand-up comedians engage with performativity to demonstrate differences between dominant and marginal cultures, regardless of whether the oppressive factors in these cultures have to do with racism or sexism.

By the same token, and following in the footsteps of Jewish American and African American comedians, female Muslims employed in the tradition of stand-up challenge the concept of difference through performativity. Muslim women and their choice of clothing are constantly highlighted in debates on difference in the West. As Schmidt puts it, "The intersection of race, religion, and womanhood culminates in the image of the veiled woman" (Schmidt 2014). Stereotypes of Muslim women also suggest that they cannot speak for themselves. Indeed, not only the agencies of Muslim women but also their very realities and individualities are overlooked. This echoes the concern of African American feminism that White feminism neglects Black, poor, and queer women and does not keep intersectionalities of race, class, and sexuality in mind.

Comedians Tissa Hami and Shazia Mirza use a veil, or more precisely, the act of wearing a veil, in their performances to re-enact this cluster of socially established meanings. 
However, they do it in a different manner. Simply wearing a veil in a comedy club, a space that is completely unexpected and almost inevitably includes the drinking of alcohol and perhaps even a bar, alters the performance. The use of the veil in a comedy club draws on religious attire that spectators are familiar with while juxtaposing it with a non-religious (as well as non-political) space. Both women also remove the veil at some point in their routines-and then, in some cases, put it on again. A veiled woman obviously does not wear a veil all the time; she puts it on, takes it off, and puts it on again in the normal course of her life. In this sense, it is a repetition of a normal performance, but done in a different manner, i.e., in front of the audience, and it undermines the stereotype of non-agency or lack of choice-and certainly silence, since the performer both exhibits and comments on the act. Hami actually refers to the removal of her veil on stage as a "strip-tease", thus emphasizing control of her own body (Hami 2013).

I conclude here by acknowledging that although performativity, incongruity, and everydayness are discussed separately for analytical purposes, they work in tandem in stand-up routines. For instance, Hami deploys incongruity by drawing on the "common knowledge" that women in Muslim countries are stoned and providing the incongruous, absurd answer to the question, "Why aren't there more female Muslim stand-up comedians?", "I didn't want the competition, so I stoned them" (Hami 2013). As a veiled woman referring to stoning, she performs a pious Muslim (or the stereotype thereof), but her performance is different and undermines the accepted meaning by virtue of incongruity.

\section{Everydayness}

In his 1927 masterpiece, Being and Time, German philosopher Martin Heidegger (2019) made a case for the importance of thinking about the meaning of Being, pointing out that because the act of Being is so simple, it tends to be overlooked. Everydayness is similarly both a fundamental feature of life and little recognized. As Henri Lefebvre confirms in his 1987 The Everyday and Everydayness, "The everyday is the most universal and the most unique condition, the most social and the most individuated, the most obvious and the best hidden" (Lefebvre 1987). Hamid Dabashi's 2013 Being Muslim makes a case for a transition from the mainstream portrayal of Muslims to the portrayal of "Muslims-being-inthe-world" through a new language of hermeneutics that focuses on geography and race. To transition from the language of "Islam and the West" and "religion versus secularism", he says one must communicate Islam as a cosmopolitan world culture realized also in the everyday lived experiences of Muslims. In this way, the public mind is exposed to alternate images and rhetoric that can portray the diversity of Muslims and Islam through representation of the everyday. Dabashi argues that "The task is not to retrieve the sacred and to posit it against the secular-but, instead, to re-imagine the sacred in the immediate vicinity of its current worldliness" (Dabashi 2013).

Nouri Gana $(2008,2009)$ points out that Arab American and Arab Muslim life narratives, i.e., biography and autobiography, especially impact public discourse because they reveal multiple everyday experiences instead of a single representation. This point is significant because comedy, and perhaps especially ethnic comedy, since it necessarily includes self-reference, is highly autobiographical. "Stand-up comedy", Gilbert contends, "is a powerful form of autobiographical performance unique in its simultaneous construction of personal identity and cultural critique". To my knowledge, everydayness has not been identified as a technique in Muslim American stand-up comedy. Since everydayness in the Muslim American popular culture sphere has, however, been discussed in terms of fiction, life narratives, and autobiography, I will begin the discussion here with two brief illustrations of everydayness from that type of work in order to clarify the concept.

Diane Abu-Jaber's novel Crescent is one example of a work of fiction that offers alternate, more realistic representations of Arab American lives by focusing on individual and communal everydayness in a diasporic community instead of on a single representation. Crescent is a love story between an Iraqi American chef in a café in Los Angeles and an exiled Iraqi professor of Near Eastern studies. The novel describes the Arab American 
community and the characters' relationships with their transnational identities, with each other, and with cooking. In Crescent, avoiding stereotypes by highlighting everyday topics, such as cooking and romance, serves to de-stereotype and to de-politicize Arabness. British Muslim author Shelina Zahra Janmohamed's (2009) novel Love in a Headscarf is another example. Janmohamed explains: "I went into a bookshop promoting literature about Middle Eastern women and all the book covers showed women in black veils and they were about escaping from slavery and forced marriages. I looked at them and thought none of them told my story. That's why I decided to write a book. I wanted people to stand in my shoes so I wrote a quirky, irreverent book" (Akbar and Taylor 2010). Set in London, the novel's protagonist, also named Shelina, wears a headscarf. Secular Muslims interpret Shelina's hijab as a sign of backwardness, while non-Muslim characters, such as Anne, tell her, "You Muslim women are oppressed, forced to cover up and not express yourselves. You have to stay at home and men run everything". This is despite the fact that Shelina is a single woman, a traveler, and a student at Oxford. Janmohamed's novel depicts everyday life as perceived by the female "Other" in an Islamophobic world in which popular culture is also dominated by non-Muslim women.

Everydayness is especially relevant to and effective in the routines of Muslim American stand-up artists because dealing with stereotypes and vilification has become an everyday element of Muslim life. Therefore, as they follow in the footsteps of their peers from other minority groups, Muslim American comedians also consciously engage with the technique of everydayness. Autobiographical everydayness establishes rapport with the audience and challenges stereotypes about Muslims as a collective by highlighting daily experiences of individuals. "We are talking to white Americans, we are saying 'this is what it's like to be Arab post 9/11 in the United States'", explains Maysoon Zayid (Michael 2011).

"Flying while Muslim" is an instance of everydayness frequently engaged in AngloAmerican Muslim stand-up comedy. Travel and going to the airport is an everyday experience for Muslims, as for others. Azhar Usman, a member of the Allah Made Me Funny troupe referred to above, highlights how travel is a common, everyday part of the life of a stand-up artist in particular: "I love being a comic but I tell you what my least favorite thing is all the travelling, ok, and the worst part about it is the moment when I have to walk into the airport. Come on people, you can write your own joke right there". Usman is evidently referring to racial profiling, which increased after 9/11, when people who "look Muslim" (Usman himself has a very substantial beard) were regarded as suspicious and singled out for searches. "The minute I get on a plane, people are in shock", Usman jokes (Axis of Evil 2006). "Whenever I get on a plane", Ahmed Ahmed says, "I always know who the air marshal is. It's the guy holding People Magazine upside down looking right at me" (Omidvar and Richards 2014). "Are you selected for random search even when you are dropping a friend at the airport?" asks Dean Obeidallah (Obeidallah 2008). What Obeidallah is saying is that this is his everyday life, his normal. "Dress white, make your flight", he advises. "It means two words: Banana Republic, my friends. Khaki pants, polo shirt with a little animal like an alligator or a tiger. No camel" (Obeidallah 2008). Similarly, references are made to the new Muslim disease, "9/11-itis", where one is afraid to go to the mosque or to wear a headscarf. Being profiled and scapegoated in an Islamophobic environment has become a common, everyday experience. As a cerebral palsy patient who is also Palestinian, Maysoon Zayid has her own autobiographical twist on the everyday experience of being profiled. "I am not afraid to go to Palestine! I am afraid to go to Newark Airport!", she says. "Because when I walk into an airport, security sees an Arab trying to board a plane, and we don't have a good record. And they don't see just an Arab, they see a shaky Arab, and they're like, that bitch is nervous!" (Zayid 2006).

Despite their fears, Anglo-American Muslim performers of stand-up comedy continue to travel, and the popularity of post-9/11 comedy tours such as Allah Made Me Funny and the Axis of Evil has led to even more travel. In his article "Laughter the Best Medicine: Muslim Comedians and Social Criticism in Post-9/11 America", Amaringth Amarasingam concludes that Islamophobia is a major contributing factor to the increase in traveling 
by Muslim American stand-up artists. "Such ignorance has put Muslim comedians into overdrive- they tour excessively, do dozens of interviews every week, and are dedicated to promoting a better image of Arab and Muslim Americans" (Amarasingam 2010). The comedians incorporate this aspect of autobiographical everydayness into their routines.

Family and marriage are also a fundamental part of autobiographical everydayness, as in the examples from the literature above. The outstanding solicitousness of Muslim and Arab parents is a favorite topic. It is relatable since anyone who has parents has particular or peculiar relations with them and has to negotiate those relations. Referring to the increase in concern and worry for one's children during the COVID-19 pandemic, Egyptian Canadian Muslim comedian Salma Hindy jokes that her parents have, since the global outbreak, obtained PhDs in WhatsApp to frequently touch base (the joke has an "in" part, i.e., the fact that WhatsApp is wildly popular throughout the Middle East across the generations) (Hindy 2020). Several comedians share their parents' reactions to their offsprings' choice of stand-up comedy for a career. "My dad, when we started out, he didn't know what I was doing - he just knew that I shook and was in a club", says Maysoon Zayid. "So he asked me, 'Are you a stripper?' When he found out I wasn't stripping he was ecstatic. He was like, 'OK, you're just telling jokes and your pants are on?'" With regard to her mother, she says. "I'll go on ' 60 Minutes', and whereas other parents would be like, 'You did a great job, I'm so proud of you', my mother will be like, 'Your hair-it was not nice'" (Zayid 2006).

As for marriage, Shazia Mirza, characterizing her father as a Saddam Hussein-type figure, jokes: "He had this regime going at home. He told my mother, 'You've got to get your daughter into the kitchen, to teach her to cook and clean, or no one will want to marry her.' He told me: 'The only way you're going to get a decent husband is if you're in a decent profession yourself' (Mirza 2017). "Good thing I got married before Trump's Muslim ban went into effect", Mirza says. "My husband is an Arab Muslim refugee who came here on a K1 fiance visa. If Trump had his way, I would die a virgin" (Mirza 2017). Again, controversy with family about marriage and concerns with marriage or "love life" are a part of the everyday of many or most people of all cultures, but not quite in the same ways in a Muslim family Mirza humorously depicts.

By including examples of everydayness from their own lives that spectators can relate to, comedians hope to subvert common stereotypes of Arabs and Muslims and present images of themselves as "normal". Azhar Usman, in fact, makes this explicit in his closing words in performances in the "Allah Made Me Funny" tour: "We say this all the time at the end of the shows, we tell the audiences that once you've watched the show and you've been with us, you are now officially part of the Allah Made Me Funny family, and that's because all of us are a family", he explains (Usman 2003).

\section{Conclusions}

Stand-up comedy, depending on the form of humor used and topics chosen, can be a means of relaying information about different cultures and identities. With the aim of countering Islamophobia, Muslim American comedians, working principally after 9/11, have thus been creating a space for their audiences to form new understandings that place Muslims in social and cultural contexts different from what they might have initially imagined. Offering perspectives as the Other by emphasizing the absurdity of common perceptions puts audiences in a position in which they (hopefully) begin to question their own assumptions of the stereotyped group. Highlighting the increasing social anxiety channeled toward Muslims as a group, Anglo-American Muslim stand-up comedians subvert the stereotypes of "Arab = Muslim", evil terrorist, and the veiled and voiceless woman. Through skillful deployment of the technique of everydayness, combined with performativity and incongruity, the comedy routines allow for disruption of a distorted "common sense".

To counter stereotypes of Arabs and Muslims, knowledge producers need to target all types of audiences, including consumers of popular culture, who are certainly a large 
population. Arab and Muslim voices countering stereotypes must also be heard in various mediums so that a more "real" social knowledge reaches everyone. In the same way that intellectuals use certain media and a certain rhetoric to share knowledge relevant to Orientalism and racism with their audiences, stand-up comedians use particular platforms, types of humor, and topics to spark social change in a way that requires a repertoire of comedic techniques and skilled artistry. As comedians have more flexibility than academics in their manner of presentation, they are able to engage with different audiences on various topics and in different tones. With a license to serve as a "spokesperson, as a mediator, an articulator of culture, and as a contemporary anthropologist" (Mintz 1985), stand-up comedians "simultaneously perform self and culture, offering an often acerbic social critique sanctioned as entertainment because it is articulated in a comedic context" (Gilbert 1997).

Early stand-up comedians such as Richard Pryor, for example, have long been considered contributors to social critique, and influenced by him and by other comedians from other minority groups, Muslim stand-up comedians are also shifting knowledge about Muslims from the academic space to the space of popular culture. As alternate interlocutors, these artists, as Amaringth Amarasingam expresses it in his article "Laughter the Best Medicine: Muslim Comedians and Social Criticism in Post-9/11 America", take on the role of "organic" or "amateur" intellectuals (Amarasingam 2010). Muslim American and Muslim British stand-up comedy can therefore be seen as an attempt to educate a wide and diverse audience on Islamophobia and the vilification of Muslims in a post-9/11 America.

Funding: This research received no external funding.

Institutional Review Board Statement: Not applicable.

Informed Consent Statement: Not applicable.

Data Availability Statement: Not applicable.

Conflicts of Interest: The authors declare no conflict of interest.

\section{References}

Akbar, Arifa, and Jerome Taylor. 2010. The many faces behind the veil. The Independent, January 13.

Akin, Adetunji. 2016. Stand-Up Comedy and Addressivity: The Example of Joan Rivers. In Advances in Linguistics and Communication Studies (ALCS) Book Series. Millcreek: Western Governer's University.

Allah Made Me Funny. 2003. Available online: https://web.archive.org/web/20110724174653/http://www.bass-schuler.com/ allahmademefunny.php4 (accessed on 15 March 2021).

Amarasingam, Amarnath. 2010. Laughter the Best Medicine: Muslim Comedians and Social Criticism in Post-9/11 America. Journal of Muslim Minority Affairs 30: 463-70. [CrossRef]

America at a Crossroads. 2007. Available online: https://www.imdb.com/title/tt0952933/ (accessed on 15 March 2021).

Axis of Evil. 2006. Available online: https:/ / www.imdb.com/title/tt1018867/ (accessed on 15 March 2021).

Bilici, Mucahit. 2010. Muslim Ethnic Comedy: Inversions of Islamophobia. In Islamophobia/Islamophilia: Beyond the Politics of Enemy and Friend. Bloomington: Indiana University Press, p. 196.

Bilici, Mucahit. 2012. Finding Mecca in America: How Islam Is Becoming an American Religion. Chicago: University of Chicago Presss, p. 177.

Butler, Judith. 1988. Performative Acts and Gender Constitution: An Essay in Phenomenology and Feminist Theory. Theatre Journal 40: 519-43. [CrossRef]

Chapelle. 2020. Available online: https:/ / www.youtube.com/watch?v=U4_9Lgym-yA (accessed on 16 March 2021).

Dabashi, Hamid. 2013. Being a Muslim in the World. New York: Palgrave MacMillan, p. 8.

Double, John Oliver. 1991. An Approach to Traditions of British Stand-Up Comedy. Ph.D. thesis, University of Sheffield, Sheffield, UK; pp. $15-20$.

Gana, Nouri. 2008. In Search of Andalusia: Reconfiguring Arabness in Diana Abu-Jaber's Crescent. Comparative Literature Studies 45: 228-46. [CrossRef]

Gana, Nouri. 2009. Everyday Arabness. In The New Centennial Review. Michigan: Michigan State University Press, vol. 9, number 2.

Get Funny or Die Tryin. 2013. Available online: https:/ / www.amazon.com/Get-Funny-Die-Tryin-Explicit/dp/B00F4KEZ2K (accessed on 16 March 2021).

Gilbert, R. Joanne. 1997. Performing Marginality: Comedy, Identity, and Cultural Critique. Text and Performance Quarterly 17: 317-30. [CrossRef]

Hami. 2013. Available online: https:/ / www.youtube.com/watch?v=DLV4dCAXZ1c/ (accessed on 15 March 2021). 
Heidegger, Martin. 2019. Being and Time. Eastford: Martino Fine Books.

Hussain, Bilal. 2015. Muslims Never Bomb on Stage: Audience Perceptions of Muslim Standup Comedy. Ph.D. thesis, Loyola University Chicago, Chicago, IL, USA; pp. 40-45.

Hindy. 2020. Available online: https:/ / www.npr.org/sections/goatsandsoda/2020/05/26/861299425/muslim-comics-gather-overzoom-to-celebrate-eid-with-jokes-and-joy (accessed on 15 March 2021).

Janmohamed, Shelina Zahra. 2009. Love in a Headscarf. Boston: Beacon Press.

Lefebvre, Henri. 1987. The Everyday and Everydayness. Yale French Studies 73: 7-11. [CrossRef]

Limon, John. 2000. Stand-Up Comedy in Theory, or, Abjection in America. Durham and London: Duke University Press, p. 84.

Make Chai Not War. 2012. Available online: https:/ / www.youtube.com/watch?v=b-9CKp_y1lo (accessed on 17 March 2021).

Michael, Jaclyn. 2011. American Muslims Stand Up and Speak out: Trajectories of Humor in Muslim American Stand-Up Comedy. Cham: Science+Business Media.

Mintz, Lawrence E. 1985. Standup Comedy as Social and Cultural Mediation. American Quarterly 37: 71-80. [CrossRef]

Mirza. 2017. Winnipeg Comedy Festival. Available online: https://www.youtube.com/watch?v=ib YqcEB4EHM (accessed on 15 March 2021).

Mo Amer: The Vagabond. 2018. Available online: https:/ / www.netflix.com/ma-en/title/80239503 (accessed on 15 March 2021).

Omidvar, Iraj, and Anne R. Richards. 2014. Muslims and American Popular Culture. Santa Barbara: Praeger, vol. 2.

Obeidallah. 2008. Available online: https:/ /www.youtube.com/watch?v=UeWqqaclQxI (accessed on 15 March 2021).

Schmidt, Silke. 2014. (Re-)Framing the Arab/Muslim: Mediating Orientalism in Contemporary Arab American Life Writing. Bielefeld: Transcript Verlag.

Shaheen, Jack. 2001. Reel Bad Arabs: How Hollywood Vilifies a People. Northampton: Olive Branch Press.

Stand Up: Muslim American Comics Come of Age. 2009. Available online: https:/ /www.imdb.com/title/tt1016022/ (accessed on 18 March 2021).

The End of Racism. 2012. Available online: https:/ / www.youtube.com/watch?v=5R1mfw3BjM8 (accessed on 15 March 2021).

The Muslims Are Coming. 2013. Available online: https://www.amazon.com/Muslims-Are-Coming-Lewis-Black/dp/B00FEBJ1LE (accessed on 15 March 2021).

The New York Arab-American Comedy Festival. 2006. Available online: https:/ / www.youtube.com/watch?v=71YZz8fckJU (accessed on 15 March 2021).

The Socially Distant Eid Comedy Night. 2020. Concordia Forum at Concordia University in Montréal. Available online: https: / / www.youtube.com/watch?v=HAj3m3Up58Q (accessed on 15 March 2021).

Usman. 2003. Available online: http://chqdaily.com/2017/08/comedian-dean-obeidallah-comments-cathartic-activist-naturehumor/ (accessed on 15 March 2021).

Usman. 2008. Available online: https:/ / www.youtube.com/watch?v=4byvovHc_iI (accessed on 15 March 2021).

Warn Your Relatives. 2018. Available online: https:/ /www.netflix.com/ma-en/title/80213657 (accessed on 15 March 2021).

Whoopi Goldberg: Direct from Broadway. 1985. Available online: https://www.imdb.com/title/tt0457207/ (accessed on 12 March 2021).

Willett, Cynthia, and Julie Willett. 2019. Uproarious: How Feminists and Other Subversive Comics Speak Truth. Minneapolis: University of Minnesota Press, pp. 27-55.

Weinberg. 2019. Available online: https: / / www.youtube.com/watch?v=x___vOWMoQ (accessed on 16 March 2021).

Zayid. 2006. Available online: https://www.pri.org/stories/2015-07-23/muslim-comedians-its-all-about-testing-boundaries-religionand-humor (accessed on 15 March 2021).

Zimbardo, Zara. 2014. Cultural Politics of Humor in (De)Normalizing Islamophobic Stereotypes. Islamophobia Studies Journal 2: 59-81. [CrossRef] 